\title{
Determining an age for the Inararo Tuff eruption of Mt. Pinatubo, based on correlation with a distal ash layer in core MD97-2142, South China Sea
}

\author{
Yueh-Ping $\mathrm{Ku}^{\mathrm{a}}$, Chang-Hwa Chen ${ }^{\mathrm{b}, *}$, Christopher G. Newhall ${ }^{\mathrm{c}}$, Sheng-Rong Song ${ }^{\mathrm{a}}$, Tsanyao \\ Frank Yang ${ }^{\mathrm{a}}$, Yoshiyuki Iizuka ${ }^{\mathrm{b}}$, John McGeehin ${ }^{\mathrm{d}}$ \\ ${ }^{a}$ Department of Geosciences, National Taiwan University, 245 Choushan Road Taipei, Taiwan \\ ${ }^{\mathrm{b}}$ Institute of Earth Sciences, Academia Sinica, P.O. Box 1-55, Nankang, Taipei, Taiwan \\ ${ }^{\mathrm{c}}$ US Geological Survey, Department of Earth and Space Sciences, University of Washington, USA \\ ${ }^{\mathrm{d}}$ US Geological Survey, Reston, USA
}

Available online 30 March 2007

\begin{abstract}
The largest known eruption of Mt. Pinatubo in the late Quaternary was the Inararo Tuff Formation (ITF) eruption, roughly estimated as five times larger than the 1991 eruption. The precise age of the ITF eruption has been uncertain. Here, a correlative of the ITF eruption, Layer D, is identified in marine sediments, and an age obtained. Tephras were identified in core MD97-2142 of Leg II of the IMAGES III cruise in northern offshore of Palawan, southeastern South China Sea $\left(12^{\circ} 41.33^{\prime} \mathrm{N}, 119^{\circ} 27.90^{\prime} \mathrm{E}\right)$. On the basis of the geochemical and isotopic fingerprints, Layer D can be correlated with the ITF eruption of the modern Pinatubo-eruption sequence. By means of the MD97-2142 SPECMAP chronology, Layer D was dated at around $81 \pm 2 \mathrm{ka}$. This estimated age of the ITF eruption and tephra Layer D coincides with an anomalously high $\mathrm{SO}_{4}^{-2}$ spike occurring within the 5 millennia from 79 to $84 \mathrm{ka}$ in the GISP2 ice core record.
\end{abstract}

(C) 2007 Published by Elsevier Ltd.

\section{Introduction}

The 1991 eruption of Mt. Pinatubo in the Philippines produced the most voluminous stratospheric volcanic aerosol cloud of the 20th century (Bluth et al., 1992). It also provided a rare opportunity to observe the effects of a sulfur-rich explosion on climate with the use of modern instruments. Consequent studies clearly revealed surface air temperatures over the Northern Hemisphere continents cooler than normal by up to $2{ }^{\circ} \mathrm{C}$ in the summer of 1992 and warmer than normal by up to $3{ }^{\circ} \mathrm{C}$ in the winters of 1991-1992 (Robock, 2002). In terms of volume, the 1991 eruption was not the biggest eruption in the modern Pinatubo-eruption record (Newhall et al., 1996). The Inararo Tuff Formation (ITF) eruption, forming the basal

\footnotetext{
${ }^{*}$ Corresponding author. Tel.: + 886227839910x615; fax: +886227839871 .

E-mail address: china@earth.sinica.edu.tw (C.-H. Chen).
}

deposit of the modern Pinatubo sequence, was estimated to have been at least five times larger in volume than the 1991 eruption. The ITF event marked the birth of the modern Pinatubo volcano edifice (Newhall et al., 1996). However, the precise age of the ITF eruption, though estimated to be older than $43 \mathrm{ka}$, is still an issue of debate due to ${ }^{14} \mathrm{C}$-dating limitations and strong weathering of the deposits (Newhall et al., 1996; McGeehin J., unpublished data). The 1991 eruption of Mt. Pinatubo serves as a good example of some of the difficulties that have a risen in estimating a more precise age for the ITF eruption. During the 1991 eruption, volcanic ash was widely dispersed westward over the South China Sea (SCS) (Wiesner et al., 1995, 2004). If the eruption types characteristic of modern Pinatubo eruptions and the wind system in the SCS have not significantly changed over the past $100 \mathrm{ka}$, then volcanic ash of the ITF eruption could have been deposited in the SCS. The purpose of this paper is to identify ash from the ITF eruption in the SCS basin and to obtain a more robust age for the ITF 
eruption using the tephrostratigraphic sequence and the SPECMAP chronology of the marine core. Another aim is to determine if the $\mathrm{SO}_{4}^{-2}$ record in Greenland ice core showed any positive anomaly at that time.

\section{Sampling and methods}

Core MD97-2142 of Leg II of the IMAGES III cruise was raised in June 1997 from north of Palawan, southeastern SCS $\left(12^{\circ} 41.33^{\prime} \mathrm{N}, 119^{\circ} 27.90^{\prime} \mathrm{E}\right)$, at a water depth of $1557 \mathrm{~m}$ (Fig. 1). Total recovered length of this core was $35.91 \mathrm{~m}$. An age model for the core has been derived from the marine oxygen isotope stages (MIS), providing a continuous record for about the past $870 \mathrm{ka}$, with sedimentation rates varying between 5 and $15 \mathrm{~cm} / \mathrm{ka}$ (Wei et al., 2003). The major constituents of this core are very fine-grained hemipelagic silty clays.

A total of 19 tephra layers were macroscopically observed in the upper $25 \mathrm{~m}$ of the core. Each was marked by a high magnetic susceptibility (Wei et al., 1998). For each ash layer, $1 \mathrm{~cm}^{3}$ of sediments was collected. The sediment samples were processed in an ultrasonic bath for $15 \mathrm{~min}$. Then, the $>63 \mu \mathrm{m}$ coarse fraction was separated by wet sieving. The pure and cleaned glass shards and biotite grains in this fraction were picked out by hand under stereo-microscope.

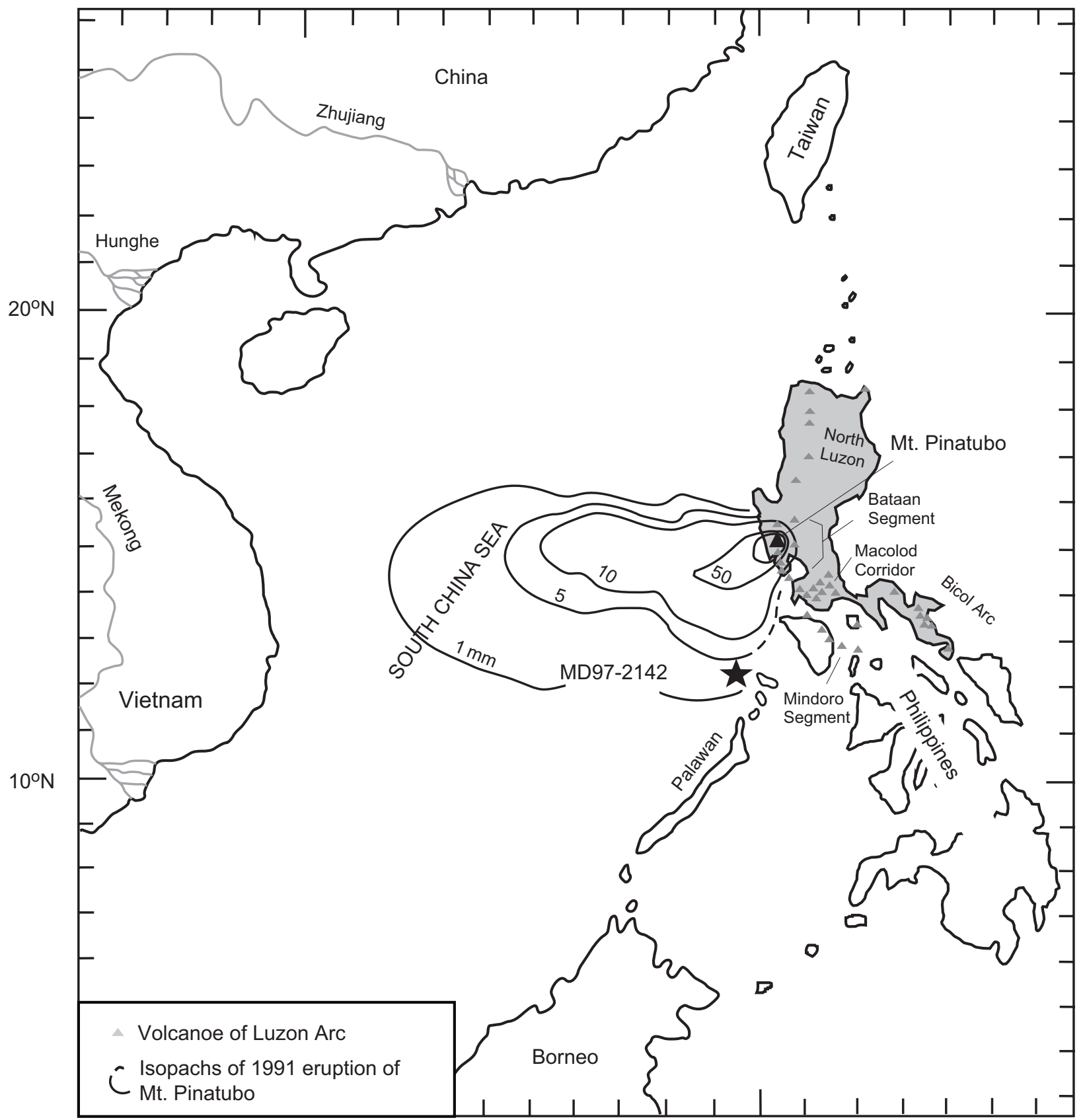

Fig. 1. Location of the IMAGES MD97-2142 core in the South China Sea and isopachs (mm) of the 1991 Pinatubo eruption (from Wiesner et al., 2004). 
The major element compositions of glass and biotite were analyzed with a JEOL JXA-8900R EPMA, using an accelerating voltage of $15 \mathrm{kV}$ and a beam current of $5 \mathrm{nA}$ with a focused $3-5 \mu \mathrm{m}$ diameter beam. Sr isotopic analyses of ca. 500-2000 glass particles per ash layer were conducted using Sr-Spec chromatography and mass spectrometric procedures on the MAT-262 (Chen et al., 2004). The ratios were normalized to ${ }^{86} \mathrm{Sr}{ }^{88} \mathrm{Sr}=0.1194$, giving a mean of 0.710226 of ${ }^{87} \mathrm{Sr} /{ }^{86} \mathrm{Sr}$ of the NBS-987 Sr. All analyses were carried out in Academia Sinica in Taiwan. For comparison, two samples collected by Prof. Newhall from unwelded (ITF-I) and welded (ITF-II) occurrences in the ITF (including $\sim 100 \mathrm{~m}$ of pyroclastic deposits) of the modern Pinatubo sequence were also analyzed.

\section{Results}

The major element compositions and $\mathrm{Sr}$ isotopic values of glass shards and biotite grains of Layer $\mathrm{D}$, at a depth of 7.50-7.52 m, are listed in Table 1. The $\mathrm{K}_{2} \mathrm{O}$ vs. $\mathrm{SiO}_{2}$ variations of Layer D and 18 other tephra layers for core
MD97-2142 are given in Fig. 2. The data indicate that Layer D is clearly distinguished from the other tephra layers by the obvious variations in $\mathrm{K}_{2} \mathrm{O}$ (lower) and $\mathrm{SiO}_{2}$ (higher) contents found in its glass shards (Fig. 2). The major elements and isotopes of glass and biotite collected from the unwelded ITF-I and the welded ITF-II on-land samples of the ITF are also shown in Table 1. The major elements of glass shards and biotite crystals in Layer D, ITF-II, and the 1991 eruptions are indistinguishable from one another (Table 1, Figs. 2 and 3). However, the glass of the ITF-I sample shows higher $\mathrm{K}_{2} \mathrm{O}$ and lower $\mathrm{Na}_{2} \mathrm{O}$ and $\mathrm{Al}_{2} \mathrm{O}_{3}$ contents.

\section{Discussion}

The MD97-2142 core site is adjacent to the active island arcs of Bataan, Macalod Corridor, Bicol, and Mindoro in the Philippines. Strong easterly winds prevail in the equatorial zone, and hence the source of tephra in the SCS is usually assumed to be from volcanic eruptions to the east, in the Philippines.

Table 1

Microprobe analyses of glass shard and biotite of tephra Layer D in IMAGES MD97-2142 core in the South China Sea, and of Inararo Tuff, Pinatubo Volcano, Philippines

\begin{tabular}{|c|c|c|c|c|c|c|c|c|}
\hline & \multirow{2}{*}{\multicolumn{2}{|c|}{$\begin{array}{l}\text { Tephra Layer D (depth } \\
7.50 \mathrm{~m}) \text { in IMAGES- } \\
\text { MD97-2142 core }\end{array}$}} & \multicolumn{4}{|c|}{ Inararo Tuff modern Pinatubo } & \multicolumn{2}{|c|}{ Pinatubo 1991 eruption } \\
\hline & & & \multicolumn{2}{|l|}{ II } & \multicolumn{2}{|l|}{ I (P-I-16) } & \multirow[b]{2}{*}{$\begin{array}{l}\text { Glass } \pm 1 \sigma \\
(n=10)^{\mathrm{b}}\end{array}$} & \multirow[b]{2}{*}{$\begin{array}{l}\text { Biotite } \pm 1 \sigma \\
(n=8)^{\mathrm{c}}\end{array}$} \\
\hline & $\begin{array}{l}\text { Glass } \\
\pm 1 \sigma \\
(n=8)\end{array}$ & $\begin{array}{l}\text { Biotite } \pm 1 \sigma \\
(n=12)\end{array}$ & $\begin{array}{l}\text { Glass } \pm 1 \sigma \\
(n=11)\end{array}$ & $\begin{array}{l}\text { Biotite } \pm 1 \sigma \\
(n=13)\end{array}$ & $\begin{array}{l}\text { Glass } \pm 1 \sigma \\
(n=16)\end{array}$ & $\begin{array}{l}\text { Biotite } \pm 1 \sigma \\
(n=6)\end{array}$ & & \\
\hline $\mathrm{SiO}_{2}$ & & $\begin{array}{l}77.30 \pm \pm 1.47 \\
39.16 \pm 0.35\end{array}$ & $40.98 \pm 0.57$ & $77.93 \pm 1.12$ & $42.46 \pm 1.29$ & $77.79 \pm 0.28$ & $40.92 \pm 0.81$ & $77.91 \pm 0.65$ \\
\hline $\mathrm{TiO}_{2}$ & & $\begin{array}{l}0.10 \pm 0.04 \\
3.65 \pm 0.16\end{array}$ & $3.16 \pm 0.17$ & $0.09 \pm 0.04$ & $3.26 \pm 0.20$ & $0.11 \pm 0.04$ & $3.58 \pm 0.08$ & $0.15 \pm 0.02$ \\
\hline $\mathrm{Al}_{2} \mathrm{O}_{3}$ & & $\begin{array}{l}13.58 \pm 0.17 \\
15.97 \pm 0.27\end{array}$ & $15.61 \pm 0.27$ & $13.30 \pm 0.82$ & $15.82 \pm 0.66$ & $12.81 \pm 0.21$ & $15.58 \pm 0.27$ & $12.89 \pm 0.31$ \\
\hline $\mathrm{FeO}^{\mathrm{a}}$ & & $\begin{array}{l}0.56 \pm 0.26 \\
14.55 \pm 0.28\end{array}$ & $14.55 \pm 0.89$ & $0.38 \pm 0.09$ & $13.80 \pm 0.64$ & $0.36 \pm 0.09$ & $14.15 \pm 0.44$ & $0.85 \pm 0.04$ \\
\hline $\mathrm{MnO} 1$ & & $\begin{array}{l}0.03 \pm 0.02 \\
0.15 \pm 0.04\end{array}$ & $0.20 \pm 0.06$ & $0.04 \pm 0.05$ & $0.12 \pm 0.05$ & $0.04 \pm 0.04$ & $0.11 \pm 0.02$ & $0.05 \pm 0.03$ \\
\hline $\mathrm{MgO} 1$ & & $\begin{array}{l}0.14 \pm 0.05 \\
17.20 \pm 0.19\end{array}$ & $16.96 \pm 0.90$ & $0.17 \pm 0.03$ & $16.18 \pm 0.76$ & $0.14 \pm 0.04$ & $16.47 \pm 0.32$ & $0.24 \pm 0.04$ \\
\hline $\mathrm{CaO} 1$ & & $\begin{array}{l}1.23 \pm 0.07 \\
0.09 \pm 0.04\end{array}$ & $0.01 \pm 0.02$ & $1.24 \pm 0.38$ & $0.10 \pm 0.12$ & $1.05 \pm 0.09$ & $0.04 \pm 0.04$ & $1.21 \pm 0.07$ \\
\hline $\mathrm{Na}_{2} \mathrm{O}$ & & $\begin{array}{l}4.16 \pm 0.33 \\
0.73 \pm 0.09\end{array}$ & $0.14 \pm 0.09$ & $4.01 \pm 0.10$ & $0.55 \pm 0.11$ & $3.06 \pm 0.13$ & $0.64 \pm 0.12$ & $3.70 \pm 0.17$ \\
\hline $\mathrm{K}_{2} \mathrm{O}$ & & $\begin{array}{l}2.91 \pm 0.52 \\
8.51 \pm 0.24\end{array}$ & $8.31 \pm 0.35$ & $2.84 \pm 0.39$ & $7.60 \pm 0.64$ & $4.69 \pm 0.16$ & $8.44 \pm 0.26$ & $3.00 \pm 0.08$ \\
\hline${ }^{87} \mathrm{Sr} /{ }^{86} \mathrm{Sr}^{\mathrm{d}}$ & & $0.70424 \pm 2$ & & $0.70436 \pm 2$ & & & & $0.70419-0.70422^{\mathrm{e}}$ \\
\hline
\end{tabular}

The major element analyses of glass shards and biotite are recalculated to $100 \%$ on a volatile-free basis. The very minor contents of $\mathrm{NiO}_{2} \mathrm{P}_{2} \mathrm{O}_{5}$ and $\mathrm{Cr}_{2} \mathrm{O}_{3}$ in biotite (total $<0.1 \%$ ) did not show in table.

${ }^{\text {a }}$ All $\mathrm{Fe}$ as $\mathrm{Fe}^{+2}$ except that in glass of Pinatubo 1991 eruption, which $\mathrm{Fe}^{+3}=0.44 \mathrm{Fe}^{\text {total }}$.

${ }^{\mathrm{b}}$ Data from Luhr and Melson (1996);

${ }^{\mathrm{c}}$ Data from Rutherford and Devine (1996).

${ }^{\mathrm{d}}$ Normalized to ${ }^{88} \mathrm{Sr} /{ }^{86} \mathrm{Sr}=0.1194$; reproducibility $(2 \sigma)= \pm 0.00004$; NBS987 ${ }^{87} \mathrm{Sr} /{ }^{86} \mathrm{Sr}=0.710226$.

${ }^{\mathrm{e}}$ Data of andesite - dacite from Bernard et al. (1996). 


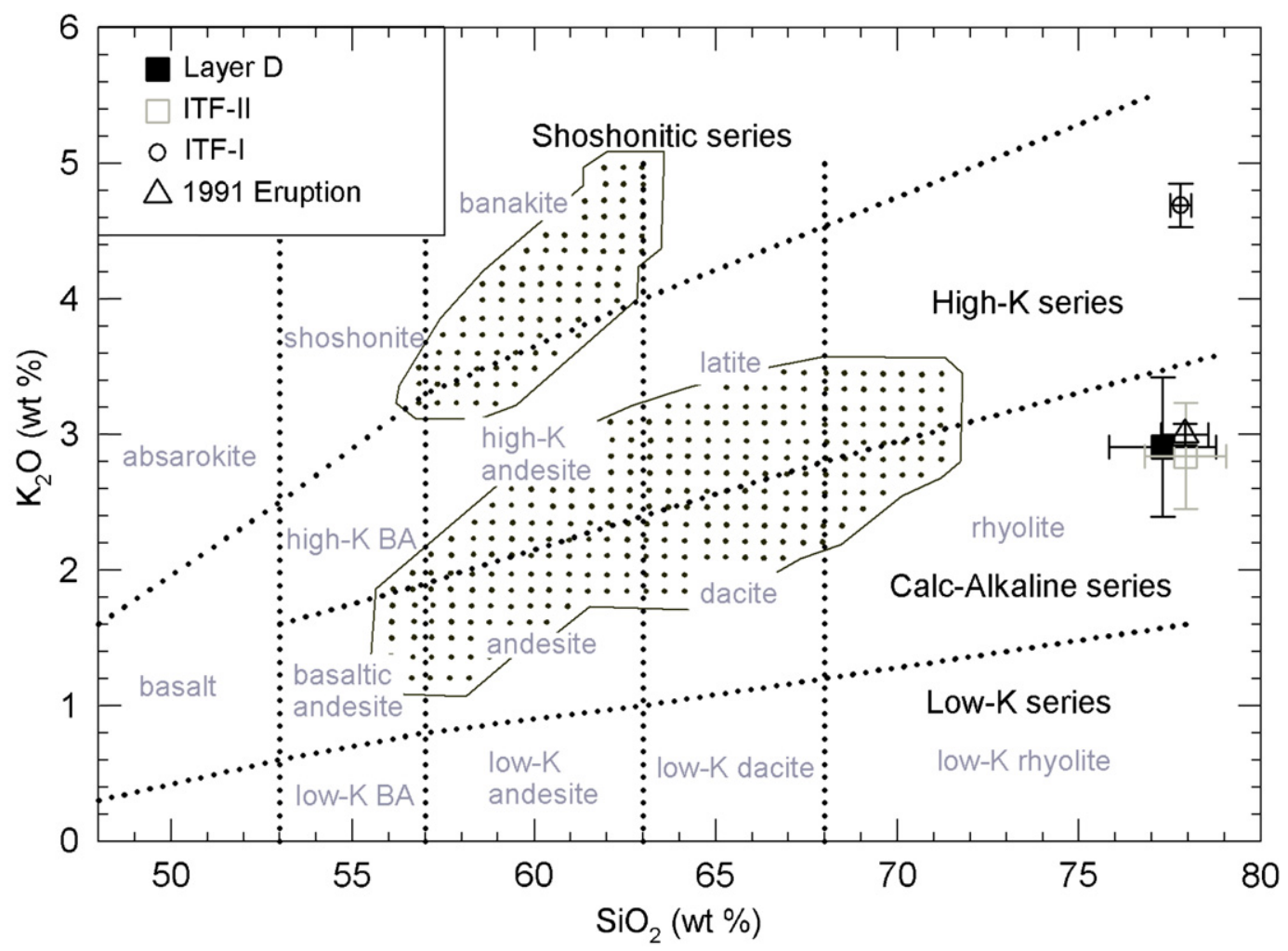

Fig. 2. $\mathrm{K}_{2} \mathrm{O}$ vs. $\mathrm{SiO}_{2}$ for glasses from tephras in MD97-2142 and from inland samples ITF-I and ITF-II. The plot shows that for those elements Layer D, ITF-II and 1991 eruption are similar. The chemical variations of 18 other tephra layers from core MD97-2142 are shown in the dotted field. Analyses for 1991 eruption were from Wiesner et al. (1995) and Luhr and Melson (1996). Classification and nomenclature of volcanic rocks accorded to their $\mathrm{K}_{2} \mathrm{O}$ content (after Taylor et al., 1981). The fields labeled rock series (nomenclature in bold) were suggested by Rickwood (1989).

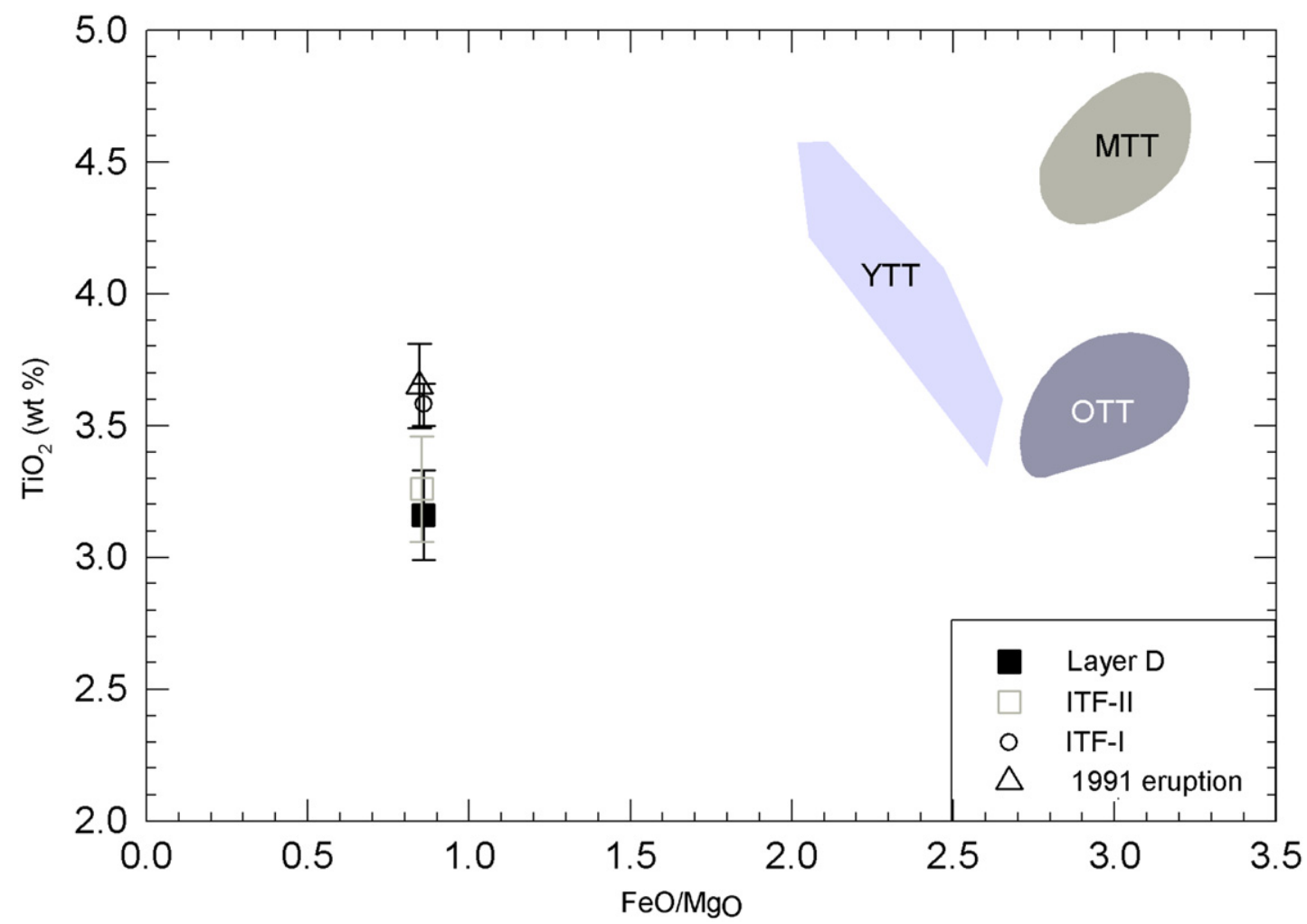

Fig. 3. $\mathrm{TiO}_{2}$ vs. $\mathrm{FeO} / \mathrm{MgO}$ for biotite crystals from Layer $\mathrm{D}$ and from inland samples ITF-I and ITF-II. The 1991 eruption data are from Rutherford and Devine (1996). The YTT, MTT and OTT represent data for the Youngest Toba Tuff, Middle Toba Tuff and Oldest Toba Tuff, respectively (Chesner, 1998). 
Based on chemical and isotopic data in the published literature, the Mindoro and Bicol arcs have relative higher $\mathrm{K}_{2} \mathrm{O}$ contents with distinct $\mathrm{Sr}$ isotopic values $>0.7051$ and $<0.7040$, respectively, (Knittel and Defant, 1988; KnittelWeber and Knittel, 1990; Defant et al., 1991; Delfin et al., 1993; Castillo and Newhall, 2004; McDermott et al., 2005). On the other hand, the $\mathrm{Sr}$ isotopic compositions of Layer D and ITF-II are 0.7042-0.7043. Therefore, the volcanic products from these volcanic island arcs could be distinguished using $\mathrm{Sr}$ isotopic ratios. For example, the $\mathrm{Sr}$ isotopic values of the Irosin Ignimbrite (>40 ka) in the Bicol arc allow it to be distinguished from the Layer D (0.7039) and 1991 Pinatubo (0.7042) eruptions. Eruptives from the Macolod Corridor show slightly higher $\mathrm{K}_{2} \mathrm{O}$ contents and $\mathrm{Sr}$ isotope ratios (0.7040-0.7059) (Divis, 1980; Wolfe and Self, 1983; Defant et al., 1988, 1989, 1991; Defant and Ragland, 1988; Knittel and Defant, 1988; Knittel et al., 1988, 1997; Miklius et al., 1991; Listanco, 1994; Mukasa et al., 1994; Knittel and Oles, 1995; Vogel et al., 2006). These eruptives could be correlatives of some of the other 18 tephra layers, but not Layer D (Ku et al., 2005). The first two rhyolitic tuff samples recovered from an inland drilling core in the Mak-Ban geothermal field, within the Macolod Corridor, were dated at 350 and $500 \mathrm{ka}$ (U/Pb Zircon SHRIMP ages), respectively (Vogel et al., 2006). These ages, much older than that of Layer D, are excluded as source candidates for Layer D. The Laguna ignimbrite was produced by an eruption that left a $20 \times 11 \mathrm{~km}$ caldera in the Macolod Corridor Volcanic Zone. The age was estimated as older than $42 \mathrm{ka}$, exceeding the limit of ${ }^{14} \mathrm{C}$-dating. Bulk compositions of the Laguna Ignimbrite showed obvious higher $\mathrm{K}_{2} \mathrm{O}(\sim 4.5 \%)$ and lower $\mathrm{SiO}_{2}(\sim 65 \%)$ contents than those obtained on glass from Layer $\mathrm{D}$, although there is overlap in the $\mathrm{Sr}$ isotopic ratios (Catane et al., 2005). Therefore, the Laguna Ignimbrite can be ruled out as the source of Layer $\mathrm{D}$, based on the chemical composition.

In Fig. 2, glass analyses for Layer D and the inland sample ITF-II are compositionally identical and overlapping. In addition, the major elemental compositions of the biotite crystals in Layer D are indistinguishable from those of ITF-I and ITF-II (Fig. 3). Analyses of biotite are a useful and reliable adjunct to glass analyses (e.g. Haynes et al., 1995; Shane et al., 2003). Moreover, the ${ }^{87} \mathrm{Sr}{ }^{86} \mathrm{Sr}$ value of the glass shards of Layer D is $0.70424 \pm 0.0002$, which is similar to the value of $0.70436 \pm 0.00002$ for ITFII. These results strongly suggest that Layer D correlates with the ITF-II eruption.

The glass of inland ITF-I sample in the Inararo Formation revealed a much higher $\mathrm{K}_{2} \mathrm{O}$ value, and lower $\mathrm{Al}_{2} \mathrm{O}_{3}$ and $\mathrm{Na}_{2} \mathrm{O}$ values, than those of Layer $\mathrm{D}$ ash and ITF-II, compared with their similar $\mathrm{SiO}_{2}$ content values. This result is very hard to explain, as the chemical variations between ITF-I and ITF-II samples were derived from fractional crystallization within magma chambers. It might be possible that there are actually two tuff layers from different sources that have somehow been lumped together. The authors reserve this as a possibility, because on-land deposits of the 1991 Pinatubo eruption exhibit a similar range in chemical composition (Luhr and Melson, 1996; Pallister et al., 1996). More certainty regarding this issue can only be derived from mapping in detail to confirm whether the deposits are synchronous eruptive deposits or not. Further geochemical analysis of proximal deposits would also be useful to assess the degree of heterogeneity of glass in the deposits (cf. Shane et al., 2007).

The age model for MD97-2142 is based on recognition of characteristic marine oxygen isotope stages (MIS). The top $35.9 \mathrm{~m}$ can be well correlated to MIS $1-21$ of the SPECMAP stack (Wei et al., 2003, Figs. 2 and 3 in that paper). Layer D (7.50-7.52 $\mathrm{m})$ is located below the MIS 5.1 event $(7.47 \mathrm{~m})$ and above the MIS 5.4 event $(8.65 \mathrm{~m})$ (Wei et al., 2003). The ages of the MIS 5.1 and MIS 5.4 events were suggested as 80 and $106 \mathrm{ka}$, respectively (Wei et al., 2003). The last appearance datum of pink Globigerinoides ruber was recorded at about $9.10 \mathrm{~m}$, which marked the approximate position of the boundary of MIS 6/5.5, around $125 \mathrm{ka}$ (Thompson et al., 1979; Wei et al., 2003). By means of these SPECMAP-based control points in the age model, the age of Layer D in the MD97-2142 core could be estimated as around $81 \pm 2 \mathrm{ka}$. The 2000 year uncertainty was adopted from the temporal resolution of sampling in the stable oxygen isotope analyses (Wei et al., 2003). This age is consistent with that of the ITF eruption at $>43,000{ }^{14} \mathrm{C}$ BP (Newhall et al., 1996; McGeehin, unpublished data). Other ${ }^{14} \mathrm{C}$ ages for the ITF event are much younger, but it is highly like that these were contaminated by modern humic acid.

The tephra deposit of the 1991 Pinatubo eruption was estimated to be less than $1 \mathrm{~mm}$ thick at the MD97-2142 core site, according to the isopachs of ash fall deposits by Wiesner et al. (2004). By contrast, it is worth noting that the thickness of Layer D at the MD97-2142 is greater than $20 \mathrm{~mm}$. Assuming that eruption types for the modern Pinatubo eruptions and the wind system in the SCS have not significantly changed over the past $100 \mathrm{ka}$, the most simplistic model of the volume of tephra fall deposits utilizing a straightforward integration of isopach data (Pyle, 1989, 1995; Fierstein and Nathenson, 1992) suggests that the eruption volume of the ITF eruption could be one order of magnitude larger than that of 1991 eruption. This observation is also consistent that the volume of the ITF eruption measured by Inararo pyroclastic flows is estimated to be $25 \mathrm{~km}^{3}$ (Newhall et al., 1996), which is at least five times that of the 1991 eruption (Paladio-Melosantos et al., 1996).

The Greenland Ice Sheet Project 2 (GISP2) ice core contains aerosols originating from both equatorial and mid to high latitude eruptions. Anomalously high $\mathrm{SO}_{4}^{-2}$ contents in the GISP2 ice core can manifestly reflect the deposition of volcanically derived aerosols (Zielinski et al., 1994). The IFT eruption and tephra Layer D may be related to one of several anomalously high $\mathrm{SO}_{4}^{-2}$ spikes occurring within the five millennia from 79 to $84 \mathrm{ka}$ in the 


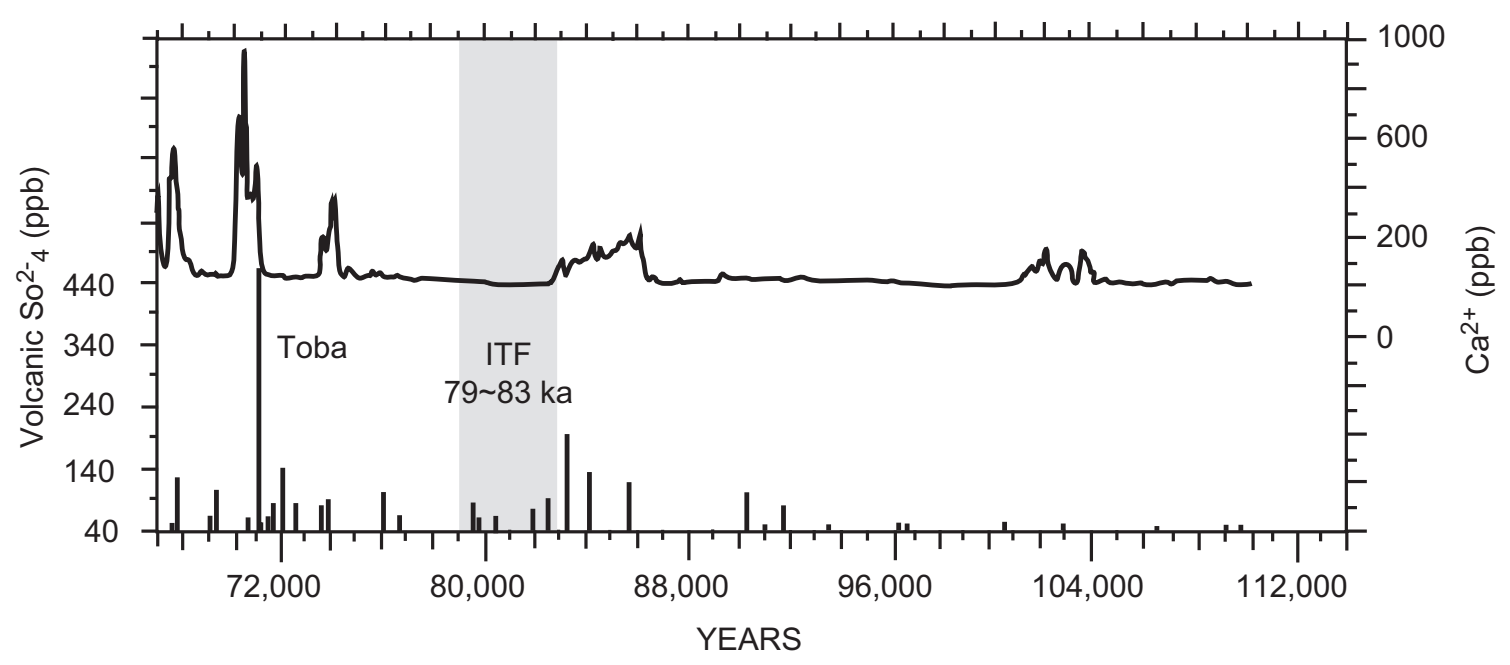

Fig. 4. The record of volcanic $\mathrm{SO}_{4}^{-2}$ and $\mathrm{Ca}^{+2}$ time series from 70 to $112 \mathrm{ka}$ in the Greenland Ice Sheet Project 2 (GISP2) ice core (Zielinski et al., 1996). Any of several anomalously high $\mathrm{SO}_{4}^{-2}$ spikes occurring within $79-84 \mathrm{ka}$ could be related to the IFT eruption.

GISP2 ice core record (Zielinski et al., 1996) (Fig. 4). Alternatively, the Aso-4 (Japan) or the Lake Atitlan (Guatemala) eruptions could be also responsible for the range of several spikes from 79 to 86 ka (Ledbetter, 1985; Zielinski et al., 1996; Machida, 1999).

Some new puzzles remain to be solved, such as clarification of the possibility of contact between the two 'Inararo' tuffs and the effects on the global climate after the ITF eruption. Any future work would need to determine appropriate means for resolving such issues. For example, the use of high-precision $\mathrm{Ar}-\mathrm{Ar}$ dating of pumice/minerals from the welded faces of the ITF and detailed mapping to look for a contact between two "Inararo" tuffs would be useful. Analysis of the oxygen isotopes of planktonic foraminifera before and after ITF eruption by means of high-resolution sampling might shed light on climate perturbations associated with the eruption.

\section{Conclusions}

The major elements and isotopes of glass and biotite crystals in Layer D and ITF-II eruptions are indistinguishable from each other. These findings strongly suggest that Layer D is a correlation of the ITF eruption of the modern Pinatubo sequence. By means of the MD97-2142 SPECMAP chronology, the age of Layer D in the MD97-2142 has been estimated at $81 \pm 2 \mathrm{ka}$. Furthermore, this IFT eruption and tephra Layer D could be related to one of several anomalously high $\mathrm{SO}_{4}^{-2}$ spikes occurring within the five millennia from 79 to $84 \mathrm{ka}$ ago in the GISP2 ice core record (Zielinski et al., 1996).

\section{Acknowledgments}

Marc De Batist and an anonymous reviewer are thanked for constructive and thoughtful reviews. Editorial handling and valuable comments by the guest editor, David Lowe, are gratefully acknowledged. The research was supported by the National Science Council, Republic of China, under CCH Grants of NSC93-2116-M-001-003 and NSC94-2116M-001-009.

\section{References}

Bernard, A., Knittel, U., Weber, B., Weis, D., Albrecht, A., Hattori, K., Klein, J., Oles, D., 1996. Petrology and geochemistry of the 1991 eruption products of Mount Pinatubo. In: Newhall, C.G., Punongbayan, R.S. (Eds.), Fire and Mud: Eruptions and Lahars of Mount Pinatubo, Philippines, Philippine Institute of Volcanology and Seismology. University of Washington Press, Seattle, Quezon City, pp. 767-797.

Bluth, G.J.S., Doiron, S.D., Krueger, A.J., Walter, L.S., Schnetzler, C.C., 1992. Global tracking of the $\mathrm{SO}_{2}$ clouds from the June 1991 Mount Pinatubo eruptions. Geophysical Research Letters 19, 151-154.

Castillo, P.R., Newhall, C.G., 2004. Geochemical constraints on possible subduction components in Lavas of Mayon and Taal Volcanoes, Southern Luzon, Philippines. Journal of Petrology 45, 1089-1108.

Catane, S.G., Taniguchi, H., Goto, A., Givero, A.P., Mandanas, A.A., 2005. Explosive volcanism in the Philippines. Center for North East Asian Studies, Monograph Series, vol. 18. Tohoku University, Japan, $131 \mathrm{pp}$.

Chen, C.H., Lee, M.Y., Iizuka, Y., Dehn, J., Wei, K.Y., Carey, S., 2004. The First Toba Super-Eruption Revival: Reply. Geology: Online Forum. 〈http://lists.allenpress.com/GSA/10091-7613-31-6-e55.pdf 〉.

Chesner, C.A., 1998. Petrogenesis of the Toba tuff, Sumatra, Indonesia. Journal Petrology 39, 397-438.

Defant, M.C., De Boer, J., Oles, D., 1988. The western Central Luzon volcanic arc, the Philippines: two arcs divided by rifting? Tectonophysics $145,305-317$.

Defant, M.J., Ragland, P.C., 1988. Recognition of contrasting magmatic processes using SB-systematics: an example from the western Central Luzon arc, the Philippines. Chemical Geology 67, 197-208.

Defant, M.J., Jacques, D., Maury, R.C., De Boer, J., Joron, J.L., 1989. Geochemistry and tectonic setting of the Luzon arc, Philippines. Bulletin of the Geological Society of America 101, 663-672.

Defant, M.J., Maury, R.C., Ripley, E.M., Feigenson, M.D., Jacques, D., 1991. An example of island arc petrogenesis: geochemistry and petrology of the southern Luzon arc, Philippines. Journal of Petrology $32,455-500$. 
Delfin, F.G., Panem-Conrado, C., Defant, M.J., 1993. Eruption history and petrochemistry of the Bulusan volcanic complex, implications for the hydrothermal system and volcanic hazards of Mount Bulusan, Philippines. Geothermics 22, 417-434.

Divis, A.F., 1980. The petrology and tectonics of recent volcanism in the central Philippine Islands. In: Hayes, D.E. (Ed.), The Tectonic and Geologic Evolution of Southeast AsianSeas and Islands: Part 1, American Geophysical Union, Geophysical Monograph, vol. 23, Washington, pp. 127-144.

Fierstein, J., Nathenson, M., 1992. Another look at the calculation of fallout tephra volumes. Bulletin of Volcanology 54, 156-167.

Haynes, J.T., Melson, W.G., Kunk, M.J., 1995. Composition of biotite phenocrysts in Ordovician tephras casts doubt on the proposed transAtlantic correlation of the Millbrig K-bentonite (United States) and the Kinnekulle K-bentonite (Sweden). Geology 23, 847-850.

Knittel, U., Defant, M.J., 1988. Sr isotopic and trace element variations in the Oligocene to Recent igneous rocks from the Philippine island arc: evidence for Recent enrichment in the sub-Philippine mantle. Earth and Planetary Science Letters 87, 87-99.

Knittel, U., Oles, D., 1995. Basaltic volcanism associated with extensional tectonics in the Taiwan-Luzon island arc: evidence for non-depleted sources and subduction zone enrichment. In: Smellie, J.L. (Ed.), Volcanism Associated with Extension at Consuming Plate Margins, vol. 81. Geological Society of London Special Publication, pp. 77-93.

Knittel, U., Defant, M.J., Raczek, I., 1988. Recent enrichment in the source region of arc magmas from Luzon island, Philippines: $\mathrm{Sr}$ and $\mathrm{Nd}$ isotopic evidence. Geology 16, 73-76.

Knittel, U., Hegner, E., Bau, M., Satir, M., 1997. Enrichment processes in the sub-arc mantle: a $\mathrm{Sr}-\mathrm{Nd}-\mathrm{Pb}$ isotopic and REE study of primitive arc basalts from the Philippines. Canadian Mineralogist 35, 327-346.

Knittel-Weber, C., Knittel, U., 1990. Petrology and genesis of the volcanic rocks on the eastern flank of Mount Malinao, Bicol arc (southern Luzin, Philippines). Journal of Southeast Asian Earth Sciences 4, 267-280.

Ku, Y.P., Chen, C.H., Song, S.R., Yang, T.F., Iizuka, Y., 2005. Volcanic and tectonic activity of the Macolod Corridor, Southwestern Luzon, Philippines: as inferred from Marine Tephra Study. In: AGU Chapman Conference on the Effects of Basement, Structure, and Stratigraphic Heritages on Volcano Behaviour in Philippines, p. 26.

Ledbetter, M., 1985. Tephrochronology of marine tephra adjacent to Central America. Bulletin of the Geological Society of America 96, $77-82$.

Listanco, E.L., 1994. Space-time patterns in the geologic and magmatic evolution of calderas: a case study at Taal Volcano, Philippines. Ph.D. Thesis, University of Tokyo, Earthquake Research Institute, Tokyo, $184 \mathrm{pp}$.

Luhr, J.F., Melson, W.G., 1996. Mineral and glass compositions in June 15, 1991, pumices: evidence for dynamic disequilibrium in the dacite of Mount Pinatubo. In: Newhall, C.G., Punongbayan, R.S. (Eds.), Fire and Mud: Eruptions and Lahars of Mount Pinatubo, Philippines. Philippine Institute of Volcanology and Seismology, Quezon City, and University of Washington Press, Seattle, pp. 733-750.

Machida, H., 1999. The stratigraphy and chronology and distribution of distal marker-tephras in and around Japan. Global and Planetary Change 21, 71-94.

McDermott, F., Defant Jr., F.M., Turner, S., Maury, R., 2005. The petrogenesis of volcanics from Mt. Bulusan and Mt. Mayon in the Bicol arc, the Philippines. Contributions to Mineralogy and Petrology 150, 652-670.

Miklius, A., Flower, M.F., Huijsmans, J.P., Castillo, P., 1991. Geochemistry of lavas from Taal volcano, southwestern Luzon, Philippines: evidence for multiple magma supply systems and mantle source hetrogeneity. Journal of Petrology 32, 593-627.

Mukasa, S.B., Flower, M.F.J., Miklius, A., 1994. The Nd-, Sr- and Pbisotopic character of lavas from Taal, Laguna de Bay and Arayat volcanoes, southwestern Luzon, Philippines: implications for arc magma petrogenesis. Tectonophysics $235,205-221$.
Newhall, C.G., Daag, A.S., Delfin Jr., F.G., Hoblitt, R.P., McGeehin, J., Pallister, J.S., Regalado, T.M., Rubin, M., Tubianosa, B.S., Tamayo Jr., R.A., Umbal, J.V., 1996. Eruptive history of Mount Pinatubo. In: Newhall, C.G., Punongbayan, R.S. (Eds.), Fire and Mud: Eruptions and Lahars of Mount Pinatubo, Philippines. Philippine Institute of Volcanology and Seismology. Quezon City, and University of Washington Press, Seattle, pp. 165-195.

Paladio-Melosantos, M.L.O., Solidum, R.U., Scott, W.E., Quiambao, R.B., Umbal, J.V., Rodolfo, K.S., Tubianosa, B.S., Delos Reyes, P.J., Alonso, R.A., Ruelo, H.B., 1996. Tephra falls of the 1991 eruptions of Mount Pinatubo. In: Newhall, C.G., Punongbayan, R.S. (Eds.), Fire and Mud: Eruptions and Lahars of Mount Pinatubo, Philippines. Philippine Institute of Volcanology and Seismology, Quezon City, and University of Washington Press, Seattle, pp. 513-535.

Pallister, J.S., Hoblitt, R.P., Meeker, G.P., Knight, R.J., Siems, D.F., 1996. Magma mixing at Mount Pinatubo; petrographic and chemical evidence from the 1991 deposits. In: Newhall, C.G., Punongbayan, R.S. (Eds.), Fire and Mud: Eruptions and Lahars of Mount Pinatubo, Philippines. Philippine Institute of Volcanology and Seismology, Quezon City, and University of Washington Press, Seattle, pp. 687-731.

Pyle, D.M., 1989. The thickness, volume and grain size of tephra fall deposits. Bulletin of Volcanology 51, 1-15.

Pyle, D.M., 1995. Assessment of the minimum volume of tephra fall deposits. Journal of Volcanology and Geothermal Research 69, 379-382.

Rickwood, P.C., 1989. Boundary lines within perologic diagrams which use oxides of major and minor elements. Lithos 22, 247-263.

Robock, A., 2002. Pinatubo eruption: the climatic aftermath. Science 295, 1242-1244.

Rutherford, M.J., Devine, J.D., 1996. Preeruption pressure-temperature conditions and volatiles in the 1991 dacitic magma of Mount Pinatubo. In: Newhall, C.G., Punongbayan, R.S. (Eds.), Fire and Mud: Eruptions and Lahars of Mount Pinatubo, Philippines. Philippine Institute of Volcanology and Seismology, Quezon City, and University of Washington Press, Seattle, pp. 751-766.

Shane, P., Smith, V., Nairn, I., 2003. Biotite composition as a tool for the identification of Quaternary tephra beds. Quaternary Research 59, 262-270.

Shane, P., Nairn, I., Martin, G.B., Smith, V.C., 2007. Compositional heterogeneity in tephra deposits resulting from the eruption of multiple magma bodies: implications for tephrochronology. Quaternary International, in press, doi:10.1016/j.quaint.2006.11.014.

Taylor, S.R., Arculus, R., Perfit, M.R., Johnson, R., 1981. Island arc basalts. In: Basaltic Volcanism Study Project (Ed.), Basaltic Volcanism in the Terrestrial Planets. Pergamon Press, New York, pp. 193-213.

Thompson, P.R., Be, A.W.H., Duplessy, J.C., Shackleton, N.J., 1979. Disappearance of pink-pigmented Globigerinoides ruber at 120,000 yr BP in the Indian and Pacific Oceans. Nature 280, 554-557.

Vogel, T.A., Flood, T.P., Patino, L.C., Wilmot, M.S., Maximo, R.P.R., Arpa, C.B., Arcilla, C.A., Stimac, J.A., 2006. Geochemistry of silicic magmas in the Macolod Corridor, SW Luzon, Philippines: evidence of distinct, mantle-derived, crustal sources for silicic magmas. Contributions to Mineralogy and Petrology 151, 267-281.

Wei, K.Y., Lee, T.Q., and the Scientific Party of ImAGES III/MD106IPHIS Cruise (Leg II), 1998. Late Pleistocene volcanic ash layers in Core MD072142, offshore from northwestern Palawan, South China Sea: a preliminary report. TAO: Terrestrial, Atmospheric, and Oceanic Sciences 9, 143-152.

Wei, K.Y., Chiu, T.C., Chen, Y.G., 2003. Toward establishing a maritime proxy record of the East Asia summer monsoons for the Late Quaternary. Marine Geology 201, 67-79.

Wiesner, M.G., Wang, Y., Zheng, L., 1995. Fallout of volcanic ash to the deep South China Sea induced by the 1991 eruption of Mount Pinatubo (Philippines). Geology 23, 885-888.

Wiesner, M.G., Wetzel, A., Catane, S.G., Listanco, E.L., Mirobueno, H.T., 2004. Grain size, area thickness distribution and controls on sedimentation 
of the 1991 Mount Pinatubo tephra layer in the South China Sea. Bulletin of Volcanology 66, 226-242.

Wolfe, J.A., Self, S., 1983. Structural lineaments and Neogene volcanism in southwestern Luzon. In: Hayes, D.E. (Ed.), The Tectonic and Geologic Evolution of Southeast Asian Seas and Islands, Part 2: American Geophysical Union, Geophysical Monograph, vol. 27. Washington, pp. 157-172.
Zielinski, G.A., Mayewski, P.A., Meeker, L.D., Whitlow, S., Twickler, M.S., Morrison, M., Meese, D., Alley, R., Gow, A.J., 1994. Record of volcanism from the GISP2 ice core (Greenland) since 7000 B.C. and implications for the volcano-climate system. Science 264, 948-952.

Zielinski, G.A., Mayewski, P.A., Meeker, L.D., Whitlow, S., Twickler, M.S., 1996. A $110,000-Y r$ record of explosive volcanism from the GISP2 (Greenland) ice core. Quaternary Research 45, 109-118. 